\title{
Building Coalitions for Transnational Trade Union Solidarity: Comparative Analysis of Three Campaigns from Turkey ${ }^{1}$
}

\author{
Emre Eren Korkmaz, Istanbul Kemerburgaz University, Turkey
}

\begin{abstract}
As in many other countries Turkish trade unions have become increasingly active in applying transnational mechanisms to target transnational corporations (TNCs) and suppliers that do not respect labor rights. This article focuses on the contributions of Global Union Federations (GUFs) in coordinating transnational solidarity campaigns and the European trade union movement's use of its 'social dialogue' policy to support Turkish struggles. The method of organizing transnational solidarity campaigns through a coalition building process among unions and pro-labor NGOs is explained and three solidarity campaigns from Turkey, (UPS campaign in the transport sector, Novamed campaign in the chemical sector and the DESA campaign in the textile-leather sector) are compared. This coalition building process offers suitable conditions to unite the power coming from production with the power coming from consumption and is able to put effective pressure on TNCs to respect labor rights. The ability of transnational campaigns to follow up issues and coalitions' willingness to work together for a long period determine the fate of unions' activities.
\end{abstract}

\section{KEYWORDS}

Globalization; global trade union movement; transnational corporations; transnational solidarity campaigns.

\section{Introduction}

There is a growing interest toward transnational solidarity campaigns supporting struggling workers in global trade union movements. Local and national unions use global unions and other transnational actors to gain support to target any transnational corporation (TNC) or its suppliers which refuses to respect labor rights. Global unions and many transnational organizations tend to re-structure themselves according to such increasing demands from local union movements to coordinate and target specific corporations.

As in many other countries, there is rising interest from Turkish trade unions applying transnational mechanisms to achieve their demands and in recent years, there have been many success stories from different sectors. In this article, three solidarity campaigns are analyzed from Turkey, namely the UPS campaign from the transport sector, the Novamed campaign from the chemical sector and the DESA campaign from the textile-leather sector. Combining workers' struggles at the local level with solidarity campaigns at the transnational level can apply effective pressure on TNCs to respect labor rights. This coalition building process offers suitable conditions to unite the power coming from production with the power coming from consumption.

Transnational solidarity campaigns are the products of coalition building processes among global and local trade unions and issue-based pro-labor civil society organizations. While local 
unions wage their struggle at the local level, they try to mobilize global and regional unions as well as national unions from other countries, and civil society organizations. The essential demand of these campaigns is to be recognized by the employer and end union busting practices. The second phase is to overcome legal thresholds to sign collective agreements according to the Turkish Labor Code which will be explained in section 4. It is necessary to emphasize that the power of transnational campaigns, its follow up process, and coalitions' willingness to work together for a long period determine the fate of unions' activities.

This paper begins with a literature review and recent debates on global trade union movements and its role in the globalization period are analyzed. Global Union Federations (GUFs) in coordinating transnational solidarity campaigns will be explained, and then the contribution of the European trade union movement to such campaigns will be discussed, criticizing their 'social dialogue' policy. Three solidarity campaigns from Turkey will be analyzed which succeeded in forcing TNCs and their suppliers to recognize trade unions after a long coordinated local picket struggles with transnational campaigns. As part of the field study, in depth interviews were conducted with trade union officers of local unions and global unions and archival research was done on these trade unions.

\section{Global Unions: Coordinating, Informing, Mobilizing National Unions}

Former International Trade Secretariats transformed themselves to Global Union Federations (GUFs) in 2002 to challenge newly emerging problems of globalization (Bourque and Hennebert, 2011: 2; Merz and Eckl, 2007: 1). GUFs bring trade unions from various nations together based on industry and sector. The advantage of GUFs is that they are able to collect information on their respective industries and maintain direct relations with TNCs. Unions from different countries may target a specific TNC under the coordination of GUFs. GUFs are responsible for transnational solidarity campaigns. Transnational solidarity campaigns include coordination of protest actions, sending solidarity messages, informing union members and creating public awareness in other countries about the reason for the campaign and to mobilize them (ICFTU, 2012: 82-84).

Many GUFs aim to establish long term negotiations with TNCs instead of only intervening in the course of crisis and disputes. GUFs form networks between unions from different countries operating in same TNCs; and follow the policies, strategies and operations of TNCs. Negotiating with the management over these policies provides GUFs a more institutional and systematic way of conducting with TNCs. Therefore, campaigning is done after the failure of applying formal and peaceful ways to solve disputes. Networks may allow GUFs to organize effective and wellcoordinated cross boarder campaigns with clear demands and goals. Burcu Ayan from the International Union of Food workers $\left(\mathrm{IUF}^{2}\right)$ stresses the necessity to negotiate with corporations for solving problems and if TNC does not aim to solve problems, transnational solidarity campaigns could be launched. There is a leverage point and if TNC refuses to be convinced to respect basic rights, transnational solidarity campaigns are a way of applying pressure on corporations. In these solidarity campaigns, local union's attempts to organize actions and create public pressure are crucial for success.

Campaigning is a complicated issue with specific strategies, objectives and planned steps. TNCs have vulnerable points. Campaigns targeting TNCs on their manner of conduct with their suppliers and local strikes/picket lines in key locations may harm TNCs and force them to take steps to accept demands of labor (Hodkinson, 2001: 9). Additionally, TNCs are held responsible for their supplier's working conditions. Name and shame campaigns targeting brand image is an effective tool to target TNCs. Campaigns may force a certain company to change its anti-union attitude. 
Discovering 'pressure points' of corporations is necessary to change company behaviors. (ICFTU, 2012: 109).

\subsection{Globalization and change of course for global unions}

Global trade union movements criticize neo-liberal, market-only policies; however different approaches are defended for an alternative path. The dominant approach is the reformist approach to 'civilize globalization' and regulate capitalism through global rules (Hoffer, 2006: 19). Erdoğdu (2006: 253) advocates that the 'Global Keynesian approach' of the global unions until the 1980s was converted to liberal reformism during the globalization process. Global unions accepted globalization as an unavoidable process, defended free trade but demanded regulation of world trade and the adding of a social aspect to this process instead of opposing privatization and neo-liberal reforms.

As a result of financial strength and vote power, Western European and North American trade unions have a dominant position in GUFs. While trade unions from underdeveloped countries with militant orientations generally defend decentralization by giving more priority to local struggles, trade unions from Western European countries with more social-democratic orientation prioritize signing Global Framework Agreements, engage in social dialogue with managements, participate in company management processes and aim to export the corporatist model to the Southern unions (Cumbers, et. al, 2008: 369-375).

However, in this approach, a fundamental critique of the capitalist system is missing. Even if social clauses are respected and monopolistic TNCs accept to obey core labor rights, it may not be possible to overcome inequalities and exploitation within each country and between advanced capitalist and underdeveloped countries. International division of labor, wages and all other characteristics that differentiate an advanced capitalist country from a dependent underdeveloped country located in periphery or semi-periphery would remain. Additionally, main efforts of the home country unions of TNCs to form partnership with management, and participate in their decisionmaking process should be examined to determine whether these unions perform internationalist solidarity or convert these privileges for their national interests (Anner et. al., 2006: 15).

Koç (2000: 31) advocates that international solidarity today is not a product of the world view or goodwill of global unions or unions of the advanced capitalist countries, but it is an objective obligation to counter problems arising from globalization in all parts of the world. Economic and political policies and austerity measures, continuous pressure over basic labor rights and creation of almost slavery-type working conditions motivate global unions to raise solidarity by organizing grass-root action days and attracting public attention to target certain monopolistic TNCs.

\subsection{Challenging globalization and raising transnational solidarity}

Responding to the challenges of globalization is the main concern of the global unions. The former General Secretary of International Union of Food and Allied Workers Associations (IUF), Dan Gallin, expressed his opinion in 1994 as follows: 'There can no longer be any effective trade union policy, even at the national level, that is not global in concept and international in organization' (Wills, 1998: 117). Neo-liberal policies and the transformation of the global economy broke the bases for compromise between capital-labor and state in center countries. This strengthened the approach for campaigning unionism (Fairbrother and Hammer, 2005: 421).

In 2004, the World Commission on the Social Dimension of Globalization stated that there were 65,000 TNCs with their 850,000 suppliers in the world (Papadakis, 2008: 1). Therefore a common and global approach is found to be necessary by global unions. It is clear for global unions that a 'national' and 'competitive' response to globalization would serve the interests of TNCs and 
diminish the bargaining power of the general labor movement. TNCs would benefit from competition among unions by threatening to invest in other places. The common struggle of unions may frustrate blackmailers of TNCs (Hodkinson, 2001: 7). The importance of transnational solidarity increases in today's world in which the bargaining power of the organized labor decreased due to neo-liberal policies and change in working relations such as flexibility, outsourcing, and usage of migrant labor etc. The aim of the transnational solidarity is to regain bargaining power (Anner et. al., 2006: 7-8).

Hodkinson (2001: 8) argues that there are two prominent forms of transnational solidarity which complement each other. The first is the 'top-down institutional perspective' in which ITUC and GUFs' 'official labor internationalism' aims to coordinate their affiliates to influence corporate activities and the second is the 'bottom up global local network perspective of global social movement unionism' which gathers local labor with NGOs to campaign at the grassroots level. However these ways of transnational solidarity do not necessarily contradict, but rather complement each other and effective and coordinated use of both ways would be productive to force TNCs to accept demands of workers. In the cases analyzed in this paper, it is possible to witness the combination of both forms of solidarity. While the top-down institutional perspective of official labor internationalism conducts relations with TNCs and negotiates demands of workers, the bottom up global local network perspective of local unions and NGOs adds militancy and raises public attention to the campaign.

\section{European Trade Union Movement: Devoted to Social Dialogue}

The European trade union movement and national centers are still the ones which are strong and powerful in the world despite the fact that European labor has also been challenged by serious threats and problems. Evidently, the European trade union movement is not as strong as in the past (IndustriALL European Trade Union Congress Documents, 2012). Fewer affiliates and more problems force European trade unions to find new methods of struggles. Merging processes of unions in national and European levels, using resources more efficiently, raising solidarity in a more effective way, organizing common action days and common campaigns, and actively supporting strikes and struggles of workers from other countries earn more importance for the European trade unions.

The mainstream European Trade Union Movement adopted the Keynesian-social democratic approach. This approach is close to the 'Rhineland Capitalism' which signifies corporatist arrangements of coordinated and regulated capitalist markets contrary to the market driven Anglo American type of capitalism (Blanke and Hoffman, 2007: 7). This type of capitalist policy not only recognizes but also gives a role to trade unions within the system to cooperate in formulating and implementing policies and in contributing to the re-production of capitalist system. Strong trade unions of these countries also had the opportunity to influence and lead policies of the European Labor Movement with its power gained through membership levels and financial sources. As a consequence of this mainstream approach, in the course of neo-liberal policies and austerity measures, the European Labor Movement stand to defend welfare state form of capitalism (Blanke and Hoffman, 2007: 17).

The European trade union movement strongly accepts the EU's policy of social dialogue. Social dialogue is, in essence, a 'deeply ideological' (Sadler, 2000: 148) concept and prerequisites the partnership and equality of labor and capital. According to this approach, instead of fighting and confronting each other, problems and demands of both sides should be solved via negotiations. Improving dialogue with each other will give birth to a new understanding by taking lessons of the 
history. According to this approach, a 'win-win' relationship could be established between labor and capital where an increase in productivity and efficiency would bring more profit for employers and more rights and better living conditions for workers (Numanoğlu, 2007: 55).

As Stevis (2008:4) argues, social dialogue refers to institutional arrangements based on historical compromises which are mixtures of compensatory liberalism, social democracy, Christian democracy and managerial statism. It suggests an alternative to the theory of 'class struggle' and pluralism. Catholic social thought and close relations between social democratic parties and trade unions in Europe are the main sources of this policy (Erdoğdu, 2006: 366).

In Turkish cases, the 'social dialogue' concept was exported from the European labour movement and used mainly for a limited purpose which was inviting employers to recognize the union, accept the bargaining process and initiate the negotiations.

\section{Involvement of NGOs: Activism, Militancy, Public Attention}

The empirical evidence as well as the extant literature indicates that support of the various sections of the society contributes to the success of workers' struggles (Munck, 2003: 45). Human rights organizations, student associations, consumer networks, feminist movements and various issue related organizations may coincide with their interests together with workers' demands and if the coalition could be built, activism and militancy of the movement would be raised. In most of the successful campaigns, public attention could be attracted not only through union's demands, but also with the contribution of various mass movements. Oppression towards workers by security forces or struggles of female workers etc. may first attract other movements to build the coalition and by the motivation of such a coalition, labor demands could earn the support of the public (Hored, 1995: 354).

Companies may not be considered as bodies that could do whatever they would like. They are active agents that shape and dominate the world system; however, their relations with labor, consumers, investors, states and non-governmental organizations have an impact on their choice of behaviors and policies (Ratner, 2001: 446). Issues such as child labor, forced labor, freedom of association, the right to strike and environmental issues caught the attention of a wide variety of issue related mass organizations. All these concerns along with the profit maximizing efforts of monopolies create a solid base for unions and NGOs to build coalitions. Developing strategies by complementing local struggles with transnational campaigning is not a new discovery, but new methods and forms could be invented, such as combining labor movements with the consumer activism (Anner, 2001: 2).

\section{Transnational Solidarity Campaigns: Evidence from Three Sectors in Turkey}

This article examines three transnational solidarity campaigns to support organizing efforts of Turkish workers in supply chains of TNCs, namely the UPS Turkey campaign (2010-2011) in the transportation sector, the DESA campaign (2008-2009) in the leather-textile sector and the Novamed Campaign (2005-2006) in the chemical sector.

This study argues that these campaigns might overcome legal barriers and anti-union attitudes of employers by combining local struggle with transnational solidarity and with the power coming from consumption and targeting brand image. A common goal of these campaigns for trade unions is to be recognized by employers and the ending of all kinds of anti-union attitudes. However, being recognized is not sufficient for trade unions. Trade unions' main aim is to bargain and sign collective agreements with employers and form their organizational base in workplaces. Therefore, being 
recognized and stopping anti-union pressures is just a first step forward and campaigns seek to help to take this step. The post-campaigning period of reaching the aim of signing collective agreements necessitates a follow-up processes by members of coalitions and also requires local union's to form a strong organizational base in the workplace.

These campaigns provide good cases to understand the impact of transnational networks on the initiatives of local unions which face severe challenges given the suppressive legal and political milieu in Turkey regarding labor rights. Although workers have legal rights covering core labor issues, the union Acts in force with regard to trade unions and collective bargaining procedures, bring various obstacles for workers to unionize. Transnational solidarity campaigns can help trade unions overcome these challenges. The 2821 Trade Union Act, the 2822 Collective Labor Agreement, and the Strike and Lock-Out Act were legislated by the military junta government after the 1980 coup d'état in order to suppress the labor movement which had increasingly been organized and militant before the coup. These Acts had been in effect until November 2012; however, the newly formulated 'Trade Unions and Collective Labor Relations Act' is still far from ILO (International Labour Organization) norms and continue the essence and logic of the previous ones (Özveri, 2012: 3; Birelma, 2007: 46). There will not be a debate in this article on the role of the new Code because the cases analyzed in the paper were in the period of the previous Codes.

This legal system enacted since the early 1980s has made organizing, bargaining and striking almost impossible by imposing legal thresholds and various procedures effectively used to control and limit the labor movement. Trade unions can be organized in industry-sector levels, but it is not permitted for trade unions to merge with unions from other sectors. Lawmakers determined the number of sectors. Also, the Acts intervene in the internal affairs of trade unions in details and do not recognize autonomy of trade unions. Even becoming a trade union member is a difficult process in Turkey, since workers can only become members based on the condition of registration by a public notary. ${ }^{3}$ To initiate collective bargaining, a trade union must overcome a $10 \%$ national sector threshold and 50\%+1 workplace threshold. Even in the case of overcoming such thresholds, a company has the right of objection, and may apply to the labor court and ask from the court to check that the union, who had received certificate of competency from the Ministry of Labor and Social Security to represent majority of employees, is true or not. The court cases could take a few years to conclude. Therefore, collective bargaining is an arduous process which usually takes a long time to be initiated ${ }^{4}$ (Birelma, 2007: 53). As a result of these policies, the total number of union members is 1 million according the official statistics of Ministry of Labor in July 2013 which is approximately $10 \%$ of the labour force. However, only $3 \%$ is from the private sector and the rest is public employees who could enjoy job security without feeling any threat to union membership (Ministry of Labor, 2013).

Transnational solidarity campaigns are not just for overcoming legal barriers to unionize. There are some other methods of pressure and mobbing towards union members from management of corporations. In most cases, when workers decide to unionize, they face dismissals and various methods of oppression by management including mobbing, forced resignation, threatening, and insulting. In some of these instances, workers initiate picket lines in front of plants to protest employers with the aim of gathering public attention to convince the employer to accept negotiation with the union and to reinstate dismissed union members. Nonetheless, this is, yet, another risky act, as the workers in picket lines could be arrested by the military or police forces. Only a minority of such attempts could succeed mostly as a consequence of combining the struggles of workers and trade unions together with the support of the public opinion. Thus, transnational solidarity campaigns could apply public pressure over TNCs and their suppliers to stop discrimination and mobbing towards union members. ${ }^{5}$ 


\subsection{The UPS campaign}

The UPS Campaign is the most successful campaign within these three cases. UPS is a global delivery company and the 'UPS Turkey solidarity campaign' was able to reinstate 163 dismissed union members and the local union (TÜMTIS) signed a collective agreement by overcoming legal workplace threshold in 2011.6 After the initiation of recruiting members, the local management dismissed 163 employees in order to stop unionization in the company. The reaction of the Union was to initiate picket lines in front of workplaces. The dismissals of Union members and the firing upon workers in picket lines by a sub-contractor on July 2, 2010 in Izmir were some of the reasons the Global Union $\left(\mathrm{ITF}^{7}\right)$ and European Trade Union $\left(\mathrm{ETF}^{8}\right)$ intensified its solidarity with its Turkish affiliate. ${ }^{9}$

\subsubsection{Local union-global union relations}

TÜMTİS and its global union ITF from the very beginning organized the UPS Campaign in Turkey jointly. Even before recruiting members, TÜMTİS and ITF's Global Delivery Unions Network (GDN) had a joint meeting in 2008 to plan organizing UPS employees in Turkey. The global union did not intervene just after dismissals but from the very beginning, and according to the ITF's policy of organizing global delivery companies, the global union and its Turkish affiliate collaborated.

The picket lines with 163 members brought a substantial financial burden over the local union and TÜMTİS did not have such financial sources. ITF and its European organization ETF financially supported TÜMTİS and almost 100 thousand Euros were transferred to TÜMTİS to finance picket lines. It is clear that without this financial support, TÜMTİS could not continue the picket line. ${ }^{10}$

ITF coordinated the transnational campaign, collaborating very closely with TÜMTİS in a day-to-day basis. The ITF Road Transport Section Secretary, Mac Urata, was responsible for the coordination of the campaign. ITF recruited two project managers to work for TÜMTİS in Istanbul. These managers could struggle together with workers in picket lines, educate employees, conduct research on the company, and report all developments to the international office with regard to the struggle and act as a bridge between local union (TÜMTİS), global union (ITF) and the American trade union (IBT). ${ }^{11}$

ITF's 42 ${ }^{\text {nd }}$ General Assembly in Mexico in August 2010 also had a turning point for the transnational campaign. TÜMTİS President Kenan Öztürk addressed the Assembly and asked for international support. Also TÜMTİS proposed a Resolution for the campaign. The Assembly approved this proposal. However, as Öztürk mentions, TÜMTİS had to work hard to express their campaign and convince delegates. ${ }^{12}$ The ITF also called for an international day of action to protest against UPS on September 1, 2010. In 40 cities of many countries, ITF affiliates protested at UPS offices and demanded UPS recognize basic rights of workers. ${ }^{13}$ The international day of action and new calls for new action plans forced the UPS Headquarters in the USA to intervene. They were disturbed by the rising support towards the Turkish union that harmed the image of the brand. First negotiations were done among ITF, ETF and UPS Europe and then UPS Turkey management and TÜMTİS began the negotiation process. The consequence of these negotiations was signing the protocol between parties covering almost all the demands of the union.

\subsubsection{The attitudes of European and US trade unions towards the campaign}

The ETF supported the UPS campaign very strongly. The reason for this support might be either the spirit of international solidarity or they were more willingly to challenge a US-based company. ETF officers accept that the aggressive policies of UPS in European markets and its antiunion attitude in most European countries, including the UK and Germany, and ETF affiliates had 
generated negative feelings towards UP. This negative feeling helped motivate and mobilize support for resisting Turkish workers. ${ }^{14}$

Although TÜMTİS gathered support from the ETF affiliates in a relatively short time period, it took much longer to convince the US based International Brotherhood of Teamsters (IBT) to support TÜMTİS. IBT is the strongest trade union present in UPS Headquarter. At the beginning, IBT was suspicious of TÜMTİS because they did not have much information about TÜMTISS. Additionally, they were disturbed by the mobilization of the European trade unions feeling that it might be generated by opposition to American capital. IBT were also opposed to the Resolution in the General Assembly to support TÜMTİS and the ITF's proposal for an international day of action. However, as a consequence of the intense efforts of TÜMTISS and ITF, IBT changed its attitude. This was done by constant and detailed communication together with TÜMTİS, ITF, ETF and IBT. The policy change of IBT was a turning point for the campaign and IBT's active participation in the campaign after the international day of action provided an opportunity to reach directly to the UPS Headquarters. Rising pressure on UPS from the USA and Europe forced UPS to accept negotiations and recognize the local union to solve the dispute ${ }^{15}$.

\subsection{The DESA campaign}

DESA is one of the leading leather companies in Turkey. It works as a subcontractor for many international brands such as Prada, Marks and Spencer (M\&S), El Cortes Ingles, and Mulberry. The company has 3 plants in Istanbul, Düzce and Çorlu. Unionization efforts at DESA began in April 2008 and the management's response was to dismiss forty members from Düzce plant and one female worker from the Istanbul plant. The 41 workers initiated picket lines in front of the two plants. Deri-Işs ${ }^{16}$ and its global union International Textile, Leather and Garment Workers Federation (ITLGWF) ${ }^{17}$ initiated a transnational campaign. Additionally, the attention of the feminist movement in Turkey and the Clean Clothes Campaign (CCC) at the European level was attracted by the struggle of one particular worker, Mrs. Emine Aslan (more on this below). The common campaign together with local union, global union and civil society movements would succeed in forcing TNCs (except Prada) to withdraw their orders by calling DESA to apply their Code of Conducts and audit their suppliers. This campaign forced the DESA management to negotiate with the local and global union. On August 24, 2009 the parties signed a protocol to recognize each other and DESA accepted to reinstate some of dismissed members and paid severance pay to the rest.

\subsubsection{Coalition building process among local union-global union-NGO relations}

The ITGLWF was a relatively small global union with regard to its staff and resources. Its late General Secretary, Neil Kearney, actively followed and led the campaign from the beginning together with its affiliate, Deri-İş. Kearney sent warning letters to DESA employers, came to Turkey many times for this issue, made press statements, visited workers in picket lines and negotiated with the employer directly. ${ }^{18}$ ITGLWF also preferred to collaborate with NGOs, especially with the CCC to overcome the lack of resources to initiate campaigns (Anner et. al., 2006: 19).

Together with CCC, ITGLWF not only targeted DESA, but also created pressure over DESA's customers. The CCC was effective in convincing M\&S and the ITGLWF affiliate Spanish union FITEQA-CC.OO (Federacion Industrias Textil-Piel Quimicas y Afines Confederacion Sindical de Comisiones Obreras), was effective in convincing El Cortes Ingles to stop giving orders to DESA. The ITGLWF's policy supporting its affiliate in its organizing activities through campaigns and its aim to work together with civil society organizations and local union's willingness 
to work together with local solidarity platforms, particularly organized by feminist organizations, meant a broad based coalition could be successfully formed.

Nevertheless, the ITGLWF could not mobilize its Italian affiliates. DESA's main customers were M\&S from the UK and Prada from Italy. While M\&S stopped ordering from DESA as a consequence of the transnational campaign, Prada insisted on working with DESA. While M\&S stopped ordering from DESA as a consequence of the transnational campaign, Prada insisted on working with DESA. Prada was even able to take advantage of the campaign by decreasing its costs. They refused campaigners' demands and exploited the tough position of DESA by decreasing the prices they paid for DESA's leather products. DESA was forced to meet these demands because they were losing their other main customers.

Deri-İş and ITGLWF called on Italian unions to take up this issue in their agendas and convince Prada to take steps further, but this did not occur. ${ }^{19}$

\subsubsection{Involvement of civil society in national and transnational levels}

In the case of DESA, the union could form a coalition with issue-based civil society organizations both at national and transnational levels. At the transnational level, the CCC became involved the campaign worked with the ITGLWF. Participation of the CCC added activism to the campaign where ITGLWF focused on more bureaucratic means, which meant that both would complement each other. ${ }^{20}$

At the national level, a Solidarity Platform was formed by feminist organizations. This platform was very sympathetic to the struggle of Emine Arslan who was resisting alone in front of the Istanbul plant. She had been fired for her union and picket line activity. She refused money offers from the corporation to quit her struggle and her daughter was almost kidnapped. This lady, who was about to retire and did not have any previous experience for unionization, insisted on her cause and acted together with the union which had a great impact over the fate of her struggle. Other 40 workers were picketing in the Düzce facility; however, it was far way from Istanbul and public attention was concentrated on the struggle of Mrs. Arslan. The Solidarity Platform organized actions and events together with the union or independently. The relationship was coordinated by a union officer who was also active in the feminist movement. Therefore, it would be easier to understand each other well. ${ }^{21}$

The continuous relationship between the local union, the local solidarity platform, the global union and the CCC was maintained until the protocol was signed. Over a period of one year, various events were organized and a public attention was earned. These efforts also forced some TNCs to stop ordering from DESA with the fear of a campaign that might target them as well. The union's officer was a key actor in organizing the campaign and establishing relations with each other. Her position in the union and being an activist of the feminist movement led them to formulate common policies more easily. She could be actively involved in all events and activities which were organized jointly or independently. In addition Novamed's struggle which is outlined below inspired these people and the movements to collaborate for DESA by drawing lessons from the Novamed campaign based on their experiences.

\subsubsection{Common discourse of union and employer: Social dialogue}

Deri-İs used the 'social dialogue' concept frequently in its statements to call on DESA to stop pressure on union members, respect basic rights and start negotiations. It was not just DESA, the union also called on the Düzce mayor and management of the Industrial Zone to respect social dialogue and act as an intermediary instead of oppressing workers and supporting DESA when the gendarme took members in custody twice and the management of Industrial Zone did not let them 
enter the Industrial Zone. ${ }^{22}$ The social dialogue concept was used to expose DESA to its customers/TNCs which declared Code of Conducts and expressed their commitment on social dialogue. Deri-İş used the 'social dialogue' concept to legitimize the start of negotiations and sign protocols with DESA. According to Deri-Işs, DESA is bound by Turkish legislation but as an international player, DESA should respect international standards and should negotiate with the union from the beginning. ${ }^{23}$

From the DESA side, 'social dialogue' also was widely used. In answers to letters to global unions, CCC, and DESA, it repeated very frequently its commitment to social dialogue. DESA also mentioned many times that despite the legal requirements, they accept having to negotiate with local unions, and listen to their demands just because of their policy of social dialogue. DESA management used 'social dialogue' and negotiations to stop any threat of a new transnational campaign that harms the image of DESA. ${ }^{24}$

\subsection{The Novamed campaign}

Novamed Campaign was one of the first attempts of Turkish unions to organize in Free Trade Zones where the right to organize had been legally banned at the beginning of the establishment of such Zones. Novamed is a German company producing medicines in Antalya Free Trade Zone. It is affiliated with a German monopoly, Fresenius Medical Care. Petrol-İş (Petroleum and Chemical Workers Union) started its activities in March 2005 and the majority of workers were recruited in April 2006. The employer learned about unionization on April 19, 2006 and tried to get rid of the union. By employing new workers, the employer caused the trade union to represent a minority of workers and forced the trade union to initiate a strike by using detailed procedures of the legislation in order to destroy all prestige of the union that would eventually fail when the majority of workers continue producing.

Petrol-İş had to initiate the strike on September 26, 2006 with 84 workers. Eighty-two of them were female workers so the strike was known as a strike of female workers in the public. Petrol-Işs decided to initiate a transnational campaign to find a solution to this unpromising strike. ICEM, the global union in the chemical sector, and its German affiliate IG BCE (Industriegewerkschaft Bergbau, Chemie, Energie) actively supported the strike of women workers. Also, civil society organizations, especially the feminist organizations formed solidarity committees. International delegations visited the strike and international public awareness was attracted. As a consequence of the campaign, Novamed management accepted to negotiate with the union and on December 18, 2007, parties signed collective agreement and by January 2008, all employees in strike went back to work. However, as a result of the polarization among employees, the union did not gain the majority at the end of the term of the agreement and did not renew the agreement. ${ }^{25}$

\subsubsection{Local union-global union-German trade union relations}

Petrol-Iss is one of the strongest trade unions in Turkey with regard to its number of members and financial sources. There is a well-experienced foreign affairs department with two full time officers. ICEM's official policy on organizing supply chains of TNCs had a positive impact over ICEM's and EMCEF's decision to support the Novamed strike. The ICEM Executive Committee had a meeting for supporting Novamed workers and accepted a resolution on the Novamed strike on $10^{\text {th }}$ May 2007 and called for transnational solidarity. ICEM also called for days of action to support Novamed striking workers as one of them occurred on $8^{\text {th }}$ March 2007 to support striking women workers. ${ }^{26}$

The German trade union, IGBCE, actively supported Petrol-İş in its struggle. IGBCE is a strong trade union and has influence over the leadership of ICEM. Therefore, from the beginning, it 
was easier for ICEM and IGBCE to cooperate and coordinate the campaign. IGBCE also has close relations with Petrol-İş, and this made it easier for German and Turkish trade unions to work together. ${ }^{27}$

International days of action, beginning with the $8^{\text {th }}$ of March, forced the German company to start negotiations. In September, ICEM, EMCEF and IG BCE had their first negotiation with the head office of the TNC and as a consequence of this meeting, negotiations started in Turkey. After two rounds of negotiations in October and November, parties signed a collective agreement on the $18^{\text {th }}$ December 2007 and striking workers began to work by January $2^{\text {nd }}, 2008$.

Without the transnational solidarity and public pressure, organizing the strike would have been impossible. ${ }^{28}$ The local union, global union, European Federation and German trade union the in chemical sector, namely Petrol-Iş, ICEM, EMCEF and IGBCE, were able to coordinate the transnational campaign by pressuring the headquarters in Germany, hence, a collective agreement could be signed. However, the union could not solve the polarization in the workplace and despite the success of the strike, the union could not convince other workers to join the union and three years later when the period of collective agreement ended, the union was unable to renew an agreement.

\subsubsection{Petrol-iş and ICEM debates on social dialogue}

The Petrol-İş union criticized social dialogue policy of ICEM. ICEM General Secretary Manfred Warda received a letter from Petrol-İş President Mustafa Öztaşkın on the $26^{\text {th }}$ December 2008 on the social dialogue policy of ICEM. Öztaşkın stated that:

We have been observing that the term 'social dialogue' is frequently inserted into the texts of the documents and news which are published on the ICEM website. One who reads the text gets the impression that 'social dialogue' is the dominant element of the ICEM strategy. (...) I do find it wrong. (...) What I find wrong is that a strategic approach adopted by part of the union movement in Europe sounds as though it is the strategic approach of a global federation. (...) The policies and strategies towards unions, for example, being implemented by TNCs in many continents and countries, aren't the same policies and strategies as in Europe. (...) a basic issue needs to be discussed and debated within the ICEM, in particular, under the current grave global crisis of capitalism (Petrol-İ̧s, 2008).

Warda responded to this letter two months later on the 23 ${ }^{\text {rd }}$ of February 2009 (Ref: ICEM09/ ENLT/ 15) as follows:

I am disappointed with your assertions regarding social dialogue. (...) It not only ensures the proper and necessary conditions for bargaining and mobilizing our members, but it plays a meaningful role in shaping national and European policies. (...) it means sound and constructive relationships with companies at the global level. (...) I would claim that the mechanisms of the ILO, as well as our relationships with companies (for example, those in which we have Global Framework Agreements with) have helped us a great deal in safeguarding and advancing the interests of workers. (...) conflict with Fresenius in Antalya provides a good example that we are not obsessed with using only the mechanism of social dialogue (Petrol-İş, 2009).

Petrol-İş insisted on its position regarding 'social dialogue with TNCs.' The union's proposal to the Congress, titled in November 2011 as 'European Transnationals' Labor Policies Outside 
Europe' was accepted by delegates. Petrol-İş referenced the Human Right Watch report issued in 2010 claiming that European TNCs 'forget' their sensitivity to union rights outside Europe. The union accused these TNCs of having double standards. 'Transnationals exploit the loopholes and shortcomings in Turkish labor law and violate international labor norms.' (Petrol-İs, 2011)

\subsubsection{Coalition of labor and NGOs to encounter TNCs}

The Novamed campaign was one of the first campaigns that the trade union and NGOs were able to collaborate for a long time to achieve victory for a certain labor struggle. The Novamed strike was known as a strike of women workers and women workers decided to unionize to counter company's ongoing pressures and discrimination generally based on gender issues. For instance, workers had to consult and ask for permission from management before getting pregnant. These instances attracted the attention of feminist organizations and many solidarity platforms were formed to support the Novamed strike in various cities. ${ }^{29}$

Various feminist organizations' involvement spread the information about the strike to general public opinion. Large masses were informed and the German company was exposed. Activities of solidarity platforms and the union were coordinated by a well-known feminist author/activist who is responsible for the publication of a woman's magazine of Petrol-Işs. This also made it easier for feminist organizations to engage a campaign with a trade union which would combine labor and gender issues together. ${ }^{30}$

\section{Conclusion}

Globalization impinges on labor's rights and livelihood as well as the labor movement in multiple dimensions. In many parts of the world, high unemployment rates have become structural problems. Precarious working conditions have destroyed formal work, while bolstering informality associated with severe risks; and inequalities have deepened within and between countries. At the same time, the strength of transnational corporations (TNCs) increased immensely as a consequence of neo-liberal reforms and changes in the international division of labor accompanying the process of globalization.

Monopolistic TNCs controlling specific sectors have constructed a hierarchical supply chain in all parts of the world. They have centralized and controlled the world production to a large extent, acquiring unprecedented power to influence decision making processes of national governments. At this conjuncture, new debates emerge on the role and the future of the trade union movement in the globalization period. Although, it is evident that the organizational strength of the organized labor and its political influence has declined in many parts of the world, new strategies of labor facilitate a revival of the global trade union movement in accordance with the new conditions imposed by the prevalent forces of globalization.

This article argues that there is a future for the global trade union movement, despite the ongoing trend in which labor has lost its power. Transnational solidarity campaigns are effective means for labor to achieve their basic demands. Paradoxically, the technological revolution in transportation and communication to which TNCs owe their expansion, these improvements also provide new opportunities for the trade union movement to interact with each other and act globally in more concrete and effective ways. Today, the trade union movement focuses on the weak sides of TNCs and reorganizes itself.

Local trade unions are eager to combine their organization efforts with international relations. International relations policy of trade unions began to shift more from information-sharing practices to activities for the mobilization of support for unionization. Local unions, which aims to organize 
employees working at a TNC or a supplier of TNC, also aims to attract transnational support to apply pressure over the company to respect basic labor rights.

Global unions re-organize themselves to answer emerging demands of their affiliates. Global unions focus more on organizing and coordinating transnational solidarity campaigns and negotiating with TNCs on the issues of labor rights within their supply chain. Global Framework Agreements provide more opportunity for trade unions to deal with TNCs for the global matters. Trade unions in Europe and the USA assist these attempts of GUFs to conduct relations at headquarters of TNCs. The solidarity campaigns explained in this paper demonstrate the fact that the involvement of trade unions at headquarters of TNCs facilitates more suitable conditions for initiation of negotiations and finding common grounds for an agreement. However, from the cases analyzed in this article, it is understood that 'the social dialogue' policy of trade unions of Europe create ambiguity and slow down the building process of coalitions against the violations of labor rights.

Participation of pro-labor NGOs in such campaigns and building coalitions add dynamism and militancy to the Campaign. Activities of NGOs contribute to campaigns by attracting support of the public and shaming TNC at the international level. This coalition building process may not be easy and cultural differences may create obstacles for these organizations to act together; however, focusing on common points would enable parties to struggle cooperatively.

The three solidarity campaigns in this article are important instances of local trade unions from different sectors overcoming legal barriers and union busting principles of employers by taking advantage of emerging conditions arising from the relations between TNCs and their supply chains.

\section{INTERVIEWS}

Burcu Ayan, IUF Officer, Geneva, 6 November 2012.

Christa Teller, ETF Officer, Brussels, 6 October 2012.

Fahmi Panimbang, Asian Monitor and Research Center, Project Manager, 29 October 2012.

Gün Bulut, Officer for Foreign Affairs, Petrol-İş, Altunizade Istanbul, 4 September 2012.

Kenan Öztürk, President of TÜMTİS, Aksaray-Istanbul, 1 November 2012.

Musa Servi, President of Deri-İş, Bostancı-Istanbul, 10 September 2012.

\section{NOTES}

1. This paper is part of broader research which was submitted and approved as a MA Thesis to Sabancı University/Istanbul titled 'Globalization, Global Labor Movement and Transnational Solidarity Campaigns: A Comparative Analysis of Three Solidarity Campaigns from Turkey' in January 2013. Apart from my academic studies, from 2010 to 2014, I worked as a 'Director of Organization and International Relations' in the Textile Workers Union in which I was directly involved in unionization efforts of workers and coordinated transnational campaigns. The Textile Workers Union is an affiliate of Confederation of Progressive Trade Unions of Turkey (DİSK). It is also an affiliate of IndustriALL Global Union and IndustriALL European Trade Union. My direct experience together with academic studies provides me a fertile ground to focus deeper on this issue.

2. Interview with Burcu Ayan, IUF Officer, Geneva, 6 November 2012.

3. By the new law, since November 2013, union membership is done via an electronic state system in which workers use their ID number and ID passport to enter the e-Turkey online platform and register for unions. 
4. A $10 \%$ national threshold was in force in the cases examined in this thesis. With the new 'Trade Unions and Collective Labor Relations Act' of December 2012, the national threshold was decreased to $3 \%$. For the first two years, it is $1 \%$, then 2 years $2 \%$ and after 2018 , it will be 3\%. The Adalet ve Kalkınma Partisi (AKP) Government showed this as a democratic improvement, however, by combining sectors and industries that trade unions may act within, the de facto threshold increased. For instance, for the leather sector, there were 90,000 registered workers in 2009 and with 10\%, the trade union needs 9,000 members. With the new Act, the leather and textile sectors merged and the total number of the workforce increased to 900,000 . The $3 \%$ threshold means 27,000 members and the threshold increased to $30 \%$ for that trade union. Similar problems occur in many other sectors such as transportation. Another point is the percentage of the organized labor in Turkey is almost 2\% in 2012 and the 3\% national threshold would not solve existing problems. (Interview with Musa Servi, President of Deri-İş, Bostanc1-Istanbul, 10 September 2012; Özveri, 2012: 5).

5. In Turkey legal restrictions and economic conditions such as high level of unemployment and low job security are the main obstacles for workers to unionize (Birelma, 2007: iv). Unemployment is an important problem in Turkey that effect decisions of workers to unionize. From 1980 to 2004, the workable population increased by 23 million whereas the rise of the number of employed people increased by 6 million. Privatization of state owned enterprises also dismissed approximately 300,000 workers. Economic growth in Turkey does not necessarily create employment. In 2000 and 2001, the crisis also increased unemployment rates (Birelma, 2007: 32).

6. ITF UPS Campaign Website [Online] Available at http://www.itfglobal.org/campaigns/upsjustice.cfm, [Accessed: 10 September 2012].

7. International Transport Workers Union.

8. European Transport Workers Union.

9. TÜMTIS is a trade union organizing the transportation sector. This was the first experience of TÜMTİS to organize a large foreign company. TÜMTİS had almost 1500 members in 2008 and UPS Turkey had 3,000 formal and 2000 sub-contracting employees. Therefore the success tripled the membership number of the union. After the UPS Campaign, the union succeeded to organize and signed a Collective Bargaining Agreement (CBA) with DHL, a German TNC, by organizing a similar campaign with ITF and Ver.di (German trade union) as well.

10. Interview with Kenan Öztürk, President of TÜMTİS, Aksaray-Istanbul, 1 November 2012.

11. Interview with Kenan Öztürk, President of TÜMTİS, Aksaray-Istanbul, 1 November 2012.

12. Interview with Kenan Öztürk, President of TÜMTİS, Aksaray-Istanbul, 1 November 2012.

13. ITF UPS Campaign Website. [Online] Available at http://www.itfglobal.org/campaigns/upsjustice.cfm, [Accessed: 10 October 2012].

14. Interview with Christa Teller, ETF Officer, Brussels, 6 October 2012.

15. Interview with Christa Teller, ETF Officer, Brussels, 6 October 2012; Interview with Kenan Öztürk, President of TÜMTİS, Aksaray-Istanbul, 1 November 2012.

16. Deri-Iss is the Leather Workers Union, organizing workers in leather and textile sectors. It is an affiliate of Türk-İş (Confederation of Turkish Trade Unions).

17. International Textile, Leather and Garment Workers Union.

18. Interview with Mr. Servi-President of Deri-İş, Bostancı-Istanbul, 10 September 2012.

19. Interview with Mr. Servi-President of Deri-İss, Bostanci-Istanbul, 10 September 2012.

20. Interview with Mr. Servi-President of Deri-İş, Bostancı-Istanbul, 10 September 2012.

21. Interview with Mr. Servi-President of Deri-İş, Bostancı-Istanbul, 10 September 2012. 
22. The Statement of Deri-Is, Deri-Is Archive, 16 May 2008.

23. Interview with Mr. Servi-President of Deri-İş, Bostancı-Istanbul, 10 September 2012.

24. Interview with Mr. Servi-President of Deri-Isss, Bostanci-Istanbul, 10 September 2012.

25. Interview with Mr. Bulut, Officer for Foreign Affairs, Altunizade Istanbul, 4 September 2012.

26. Petrol-İş Web Sitesi, Novamed Dosyası. [Online] Available at http://petrol-is.org.tr/ etiket/novamed, [Accessed: 10 September 2012].

27. Interview with Mr. Bulut, Officer for Foreign Affairs, Altunizade Istanbul, 4 September 2012.

28. Interview with Mr. Bulut, Officer for Foreign Affairs, Altunizade Istanbul, 4 September 2012.

29. Interview with Mr. Bulut, Officer for Foreign Affairs, Altunizade Istanbul, 4 September 2012.

30. Interview with Mr. Bulut, Officer for Foreign Affairs, Altunizade Istanbul, 4 September 2012.

\section{REFERENCES}

Asian Labour Update (ALU) (2007) 'The Strategy of Triangular Solidarity: What is international solidarity for Asian workers in the Global Factory?,' Asian Labour Update Labour Resurgence under Globalization. Issue 65, Hong Kong: Asia Monitor Research Centre.

Anner, M., Greer, I., Hauptmeier, M., Lillie, N. and Winchester, N. (2006) 'The Industrial Determinants of Transnational Solidarity: Global Interunion Politics in Three Sectors,' European Journal of Industrial Relations. Vol. 12, No. 1, pp. 7-27.

Birelma, A. (2007) Three cases of worker mobilization in contemporary Turkey. Non-Published MA Thesis, Boğaziçi Üniversitesi.

Blanke, T. and Hoffman, J. (2007) 'Towards a European Social Model Preconditions, difficulties and prospects of a European social policy,' European Trade Union Institute for Research, Education and Health and Safety (ETUI-REHS) Working Paper 2007-02. Brussels: ETUIREHS aisbl.

Cumbers, A., Nativel, C., Routledge, P. (2008) 'Labour agency and union positionalities in global production networks,' Journal of Economic Geography. 8, (3), pp. 369-387.

Erdoğdu, S. (2006) Küreselleşme sürecinde uluslararası sendikacılık. Ankara: İmge Kitabevi.

Fairbrother, P. and Hammer, N. (2005) 'Global Unions: Past Efforts and Future Prospects,' Industrial Relations, Vol. 60, No. 3, pp. 405-431.

Hodkinson, S. (2001) Reviving Trade Unionism: Globalisation, Internationalism \& the Internet. Working Paper Presented to the 29th Joint Sessions of Workshops, Grenoble, France.

Hoffer, F. (2006) 'Building global labour networks: the case of the global labour university,' Just Labour: A Canadian Journal of Work and Society. Vol. 9., Autumn, pp. 16-34.

Hored, A. (1995) 'The Practice of International Labor Solidarity and the Geography of the Global Economy,' Economic Geography. Vol. 71, No. 4 (Oct., 1995), pp. 341-363. [Online] Available at http://www.jstor.org/stable/144422, [Accessed: 26 October 2011]. 
ICFTU Web Site, (2012) A trade union guide to globalisation (second edition). [Online] Available at http://www.icftu.org/pubs/globalisation, [Accessed: 12 September 2012].

IndustriALL European Trade Union Congress Documents, 2012.

Koç, Y. (2000) Ulusötesi sermaye ve iş̧̧i hakları. No 47. Ankara: Türk-İş Eğitim Yayınları.

Ministry of Labor and Social Security, (2013) Union Statistic. July 2013, Ankara.

Munck, R. (2003) Emeğin Yeni Dünyası Küresel Mücadele Küresel Dayanışma. İstanbul: Kitap Yayınevi.

Numanoğlu, N. (2007) 'Avrupa sosyal modelinde sendikaların rolü,' Avrupa Birliği müzakere sürecinde Avrupa sosyal modeli ve sendikal haklar uluslararası sempozyum bildirileri. Ankara: Türkİş Yayınları.

Özveri, M. (2012) Toplu İş İlişkileri Yasa Tasarısı ve Sendikal Haklar. İstanbul: Birleşik Metal-İş Yayınları.

Papadakis, K. (2008) Cross-border social dialogue and agreements: An emerging global industrial relations framework? International Labour Office: Geneva.

Petrol-İşs Web Site [Online] Available at http://petrol-is.org.tr/etiket/novamed, [Accessed: 3 September 2012].

Petrol-İş Archive (2008) Letter to Mafred Warda. Istanbul.

Petrol-İş Archive (2009) Letter To Mr. Öztaşkın. ICEM 09/ENLT/15.

Petrol-İş, Archive (2011) European Transnationals: Labour Policies Outside Europe.

Ratner, S.R. (2001) 'Corporations and Human Rights: A Theory of Legal Responsibility,' The Yale Law Journal. Vol. 111, No. 3, pp. 443-545. [Online] Available at http://www.jstor.org/ stable/797542, [Accessed: 26 October 2011].

Report on Our Activities in DESA [Online] Available at http://www.deri-is.com/diger-konular/262report-on-our-activities-in-desa-duezce.html, [Accessed: 10 September 2012].

Stevis, D. (2008) International Framework Agreements Between Unions and Multinationals: Corporate Social Responsibility or Social Regulation? Paper presented at the 2008 Convention of the International Studies Association: San Francisco.

Wills, J. (1998) 'Taking on the CosmoCorps? Experiments in Transnational Labor Organization,' Economic Geography. Vol. 74, No. 2, pp. 111-130. [Online] http://www.jstor.org/stable/ 144278, [Accessed: 26 October 2011]. 


\section{BIOGRAPHICAL NOTE}

EMRE EREN KORKMAZ is a Research Assistant in the Department of International Relations at the Istanbul Kemerburgaz University in Turkey. $\mathrm{He}$ is a $\mathrm{PhD}$ candidate of the Istanbul University, Faculty of Political Sciences, International Relations Program and a graduate from Sabanc1 University Turkish Studies MA Program. From 2010 to April 2014, he worked as Director of Organization and International Relations for the Textile Workers Union, an affiliate of DISK (Confederation of Progressive Trade Unions of Turkey).

[Email: emreerenkorkmaz@gmail.com] 